\title{
The Impact of Business Life Cycle and Performance Discrepancy on R\&D Expenditures-Evidence from Taiwan
}

\author{
Shu-Chin Chang ${ }^{1}$, She-Chih $\mathrm{Chiu}^{2} \&$ Pei-Cheng $\mathrm{Wu}^{1}$ \\ ${ }^{1}$ Departmet of Accounting, Chung Yuan Christian University, Taoyuan City, Taiwan \\ ${ }^{2}$ Department of Accountancy, National Taipei University, New Taipei City, Taiwan \\ Correspondence: She-Chih Chiu, Department of Accountancy, National Taipei University, No. 151, University Rd., \\ San Shia District, New Taipei City, 23741 Taiwan
}

Received: April 22, 2017

Accepted: July 30, 2017

Online Published: August 17, 2017

doi:10.5430/afr.v6n3p135

URL: https://doi.org/10.5430/afr.v6n3p135

\begin{abstract}
The purpose of this study is to examine the impact of business life cycle and performance discrepancy on Research and Development (R\&D) expenditure. Specifically, we argue that managers of firms in different stages of business life cycle make R\&D decisions according to their perception of performance discrepancy. We investigate three stages of business life cycle: growth stage, maturity stage, and stagnant stage. Based on a sample of firms listed in Taiwan Stock Exchange, we find that managers of firms in the growth stage tend to increase R\&D expenditure when they experience positive performance discrepancy. This implies that growing firms' slack-resource-driven behavior leads to the increase in $\mathrm{R} \& \mathrm{D}$ expenditure. There is some evidence that managers of firms in the mature stage tend to increase $R \& D$ spending when they experience negative performance discrepancy, which indicates that negative performance discrepancy triggers the problem-driven search behavior of managers of mature firms.
\end{abstract}

Keywords: Business life cycle, Performance discrepancy, R\&D expenditures

\section{Introduction}

Companies in a rapidly changing environment must persistently invest in research and development (hereafter, R\&D) in order to keep their own competitiveness, which makes the investment in R\&D indispensable in the business operation. Nevertheless, the uncertain nature of R\&D may affect managers' decisions with respect to how much money they should invest in the different business life cycles. In the academic research, scholars have paid much attention to business life cycles. They indicate that business life cycle affects managers' R\&D decisions. Firms in the growth stage of business life cycle usually have high $R \& D$ expenditure, while those in the mature and stagnant stages of business life cycle usually have relatively low $R \& D$ expenditure due to the reduced competitiveness. Some scholars further indicate that performance discrepancy also affects managers' R\&D decisions. Firms tend to reduce $R \& D$ expenditure when they have positive performance discrepancy, and increase R\&D expenditure when they have negative performance discrepancy. However, little attention has been paid to how business life cycle and performance discrepancies jointly affect managerial R\&D decisions. We fill the gap.

The purpose of this study is to investigate whether managers of firms in different stages of business life cycle make different $R \& D$ decisions when they experience unexpected performance discrepancies. We propose that managers of firms in different stages of business life cycle reallocate business resources in terms of performance discrepancies in order to optimize their R\&D decisions. We classify the business life cycle into growth, mature, and stagnant stages in terms of a firm's dividend payout policy, sales growth, capital expenditures, and age. We highlight the importance of business life cycle in managers' R\&D decisions by employing the well-known aspiration performance feedback model inspired by Cyert and March (1963), which propose that organizational change is driven by an organization's aspirations and the feedback it receives in terms of its performance. We then conduct regression analysis to examine how managers shape their $\mathrm{R} \& \mathrm{D}$ decisions according to the discrepancies between actual level and aspiration level of corporate performance in different stages of business life cycle.

The sample contains Taiwanese publicly held companies during the period between 2001 and 2010. We find that managers of firms in the growth stage tend to increase R\&D expenditure when they experience positive performance discrepancy. There is some evidence that managers of firms in the mature stage tend to increase R\&D spending when they experience negative performance discrepancy. We contribute to the literature in several ways. First, we show 
that managers' R\&D decisions are not monotonic. Managers of firms in different stages of business life cycle make different $R \& D$ decisions in terms of their perception of performance discrepancy. Secondly, we provide insight on the best timing of follow up investment decisions. Our findings suggest that the most appropriate timing for firms in the growth (mature) business life cycle is increasing R\&D investments when they experience positive (negative) performance discrepancy. Finally, we add to the theories of problem-driven search behavior and slack-resource-driven behavior by showing that managers' problem-driven search and slack-resource-driven behavior may occur under certain circumstances.

\section{Literature Review and Hypotheses Development}

\subsection{Business Life Cycle and $R \& D$ Expenditure}

R\&D is a key factor of competiveness. In the era when the length of the business cycle has been expedited considerably, companies must constantly invest in R\&D projects because, as indicated by Black (1998) and Dutta et al. (1999), R\&D and its outcomes are major determinants of corporate performances and firm value. Also because $R \& D$ expenditure possesses relatively uncertain benefits as compared to capital expenditure, it is necessary for managers to understand how and when to maximize the benefit from $R \& D$ with limited resources.

Many studies have highlighted the importance of business life cycle (e.g., Miller and Friesen, 1984; Dodge and Robbins, 1992; Hanks and Chandler, 1994). Because companies have different organizational structures and strategies in every stage of the business life cycle, they must deliberate on every advantage in order to maximize the utilities of innovation. For instance, growing firms may excessively invest in capital expenditures in order to strengthen competitive advantage or to prevent potential new competitors, and their actions are affirmative by the capital market (Anthony and Ramesh, 1992). A firm's business life cycle includes growth, mature, and stagnant stages. Indicated by Miller and Friesen (1984), firms in the growth stage try to establish a unique ability for entering the market, and these firms focus on sales growth and resources in order to gain competitive advantages. In the mature stage, firms have stable sales growth, a decline in $R \& D$, and bureaucratic organizational structure. In the stagnant stage, firms are characterized by insufficient $R \& D$ and decline in earnings.

Firms' R\&D expenditures may vary with the stages of business life cycle. When firms are in the growth stage and there are only a few competitors in the market, they try to maximize their profitability through cost saving (Porter, 1998). In this stage, firms focus on customer relationship management and new product development, and hence invest much money in R\&D (Hill, 2010). In the mature stage, firms are most competitive and have their own brands. As the maturity stage progresses, firms need more investments in R\&D in order to accelerate technique innovation (Tushman and Nadler, 1986). This is because the mature firms' core competitive capabilities may fall into competitive advantage trap, which leads to more expenditures for preserving existing resources (Levinthal and March, 1993; Helfat and Peteraf, 2003). As firms enter the stagnant stage, stable resource utilization weakens their innovation (Leonard-Barton; 1992). In this stage, firms are no longer competitive and profitable, and hence they do not have sufficient resources for R\&D.

\subsection{The Effect of Performance Discrepancy on R\&D}

Based on Prospect theory, previous studies suggest that managers under potential risks tend to adjust decisions in terms of their expectations (Kahneman and Tversky, 1979; Schneider, 1992; Cyert and March, 1992; Bolton, 1993; Greve, 1998; Greve, 2003b; Greve, 2008). For instance, managers have problem-driven search behavior as they feel disappointed with corporate performance, and they restrain their own problem-driven search behavior as they are satisfied with corporate performance (Cyert and March 1992; Greve, 1998; Shimizu and Hitt, 2005; Baum and Dahlin, 2007). This behavior also applies to managers' R\&D decisions (Greve, 2003b; Chen and Miller, 2007). Some research finds that positive performance discrepancy may lead to lower R\&D level (Greve, 2003b), while other research finds that negative performance discrepancy may lead to higher R\&D level (Greve, 2003a; Greve, 2003b; Chen and Miller, 2007). This is because managers tend to adjust R\&D in order to keep their firms' long-term competitive advantages. Collectively, these studies suggest that managers tend to be a risk avoider in R\&D decisions when they experience positive performance discrepancy, while they tend to be a risk seeker in R\&D decisions when they experience negative performance discrepancy.

\subsection{Hypotheses Development}

Managers' attitude toward performance discrepancies and R\&D decisions may vary with the stages of business life cycle. Wöhrl et al. (2009) find a positive relationship between sales growth and R\&D expenditure. They also indicate that firm age may influence $R \& D$ expenditure and that young firms attach more importance to growth than to profitability. This means the positive relationship between sales growth and R\&D expenditure weakens with ages. 
They also indicate that because firms in the growth stage of business life cycle have fewer competitors and more investment opportunities, these firms are more likely to succeed if they are willing to invest in R\&D. In addition, Comin and Mulani (2009) indicate that R\&D expenditure is positively related to firm volatility. Accordingly, it is expected that firms in the growth stage of business life cycle have high R\&D expenditure, because growing firms are usually considered unstable and volatile. Although previous studies find that managers tend to keep the current situation when they perceive firm performance to be more than expected (Cyert and March, 1992; Greve, 2003b; Shimizu and Hitt, 2005; Baum and Dahlin, 2007; Chen and Miller, 2007), managers of growing firms may not be satisfied with positive performance discrepancy. Instead, managers of growing firms may spend more on R\&D projects in order to expand the market. In the case where the performance discrepancy is negative, the unfavorable outcomes may motivate managers of growing firms to search possible solutions. Thus, they are likely to spend more on $R \& D$ projects for long-term competitive advantages.

In the mature stage, managers are less likely to gain excess returns from the fiercely competitive market. McAdam and Mitchell (2010) find that firms in the mature stage of business life cycle are more conservative in the innovation activities and are less responsive to the market. Lin et al. (2012) investigate firms' risk behavior in different stages of business life cycle. They suggest that growing firms need more resources for future growth, while mature firms and stagnant firms should reduce costs for keeping competitive advantages. Similarly, Bos et al. (2013) indicate that innovation is high when an industry is young and low when the industry matures. They also find a negative correlation between R\&D and industry maturity. This is mainly because the industry becomes stable when it enters the mature stage. Firms in this industry are indolent in the innovation activities and unable to receive high gross profits. As a result, managers of these firms tend to increase the profits by reducing unit costs with mass production. They may become conservative as they experience positive performance discrepancy, which results in a decrease in R\&D. As they experience negative performance discrepancy, however, the managers may problem-driven search behavior and increase R\&D in order to maintain existing competitiveness.

In the stagnant stage, firms are less competitive and profitable. If the firms have poor performance, their managers might behave conservatively when making strategic changes (Ketchen and Palmer, 1999). Chen and Miller (2007) further indicate that firms' conservatism depends on their performance aspirations. They find that firms increase $R \& D$ search intensity as performance falls below aspirations, but there is little evidence that firms increase R\&D search intensity as performance is above aspirations. Several studies find that firms with financial distress may restrict problem-driven search behavior (Staw et al., 1981), new strategies (D’Aveni, 1989), and risks (March and Shapira, 1992). However, firms in the stagnant stage of business life cycle might have different R\&D search patterns. Latham and Braun (2009) investigate how managerial ownership and slack resource affect innovation decision when firms are encountering organizational decline. They find that stagnant firms with slack resource tend to reduce innovation in order to reserve resources. Chiang et al. (2012) indicate that stagnant firms tend to increase sales by promoting existing products rather than developing new products, and they focus more on survival ability as compared to their focuses in other stages of business life cycle. Therefore, we should observe reduced R\&D as the firms enter the stagnant stage in both the case of positive and negative performance discrepancies, because firms become more conservative in the stagnant stage than other stages and may reserve resources by reducing $R \& D$ spending. Accordingly, we expect that stagnant firms experiencing positive and negative performance discrepancies are associated with lower level of R\&D. We develop the following hypotheses:

$\mathrm{H}_{1}$ : R\&D decision is jointly determined by business life cycle and performance discrepancy.

$\mathrm{H}_{1 \mathrm{a}}$ : Firms in the growth stage increase $\mathrm{R} \& \mathrm{D}$ as they experience positive performance discrepancy.

$\mathrm{H}_{1 \mathrm{~b}}$ : Firms in the growth stage increase R\&D as they experience negative performance discrepancy.

$\mathrm{H}_{1 \mathrm{c}}$ : Firms in the mature stage reduce R\&D as they experience positive performance discrepancy.

$\mathrm{H}_{1 \mathrm{~d}}$ : Firms in the mature stage increase $\mathrm{R} \& \mathrm{D}$ as they experience negative performance discrepancy.

$\mathrm{H}_{1 \mathrm{e}}$ : Firms in the stagnant stage reduce R\&D as they experience positive performance discrepancy.

$\mathrm{H}_{1 \mathrm{f}}$ : Firms in the stagnant stage reduce $\mathrm{R} \& \mathrm{D}$ as they experience negative performance discrepancy.

\section{Research Design}

\subsection{Determination of Business Life Cycle}

Following previous studies (Anthony and Ramesh, 1992; Black, 1998), we identify a firm's stage of business life cycle in terms of the firm's life cycle descriptors: sales growth rate, dividend payout ratio, capital expenditure, and firm age. Firms in early life cycle stages usually exhibit higher sales growth, have more capital expenditures, have 
lower dividend payout ratios, and are young. A firm's sales growth rate in year $t\left(S G_{i, t}\right)$ is defined as the percentage change in net sales in year $t$, then multiplied by 100 . A firm's dividend payout ratio in year $t\left(D P_{i, t}\right)$ is defined as cash dividends in year $t$ divided by income before extraordinary items and discontinued operations in year $t$, then multiplied by 100 . A firm's capital expenditure in year $t\left(C E V_{i, t}\right)$ is defined as capital expenditure in year $\mathrm{t}$ divided by the sum of market value of equity at the end of year $t$ and book value of long-term debt at the end of year $t$, then multiplied by 100. A firm's age in year $t\left(A G E_{i, t}\right)$ is defined as the numbers years since the firm's initial operation.

We then classify the life cycle descriptors into three groups: Low, Median, and High. The median values of $S G_{i, t}$, $D P_{i, t}$, and $C E V_{i, t}$, for every firm in each year are determined using the data over the past five years, which requires at least six years of data availability for each firm. The median value of $A G E_{i, t}$ is the industrial median in the year, based on two-digit Standard Industrial Classification (SIC) code. A life cycle descriptor of which the value is the median value is grouped into Median group. A life cycle descriptor of which value is higher (lower) than the median value is grouped into High (Low) group.

We then rank firms in every year on each of the four life cycle descriptors, and then group them into three life cycle stages according to Table 1. Life cycle descriptors in the growth, mature, or stagnant stages are correspondingly given a score of zero, one, or two. For example, a firm-year with high $S G$ in the growth stage is given a score of zero; a firm-year with high $D P$ in the stagnant stage is given a score of two. We then integrate the scores into a total score by summing up the scores of life cycle descriptors for each firm in every year, named LIFECYCLE. A firm with a total score between zero and two is identified as a growing firm. A firm with a total score between three and five is identified as a mature firm. A firm with a total score between six and eight is identified as a stagnant firm. Using total score, we take into consideration the interaction among descriptors and reduce potential misclassification

Table 1. Firm-specific descriptors of life cycle stages

\begin{tabular}{|c|c|c|c|c|c|}
\hline \multirow{2}{*}{ Life cycle stages } & \multicolumn{5}{|c|}{ Life cycle descriptors } \\
\hline & $S G$ & $D P$ & $C E V$ & $A G E$ & LIFECYCLE \\
\hline Growth & $\begin{array}{c}\text { High } \\
(\text { score }=0)\end{array}$ & $\begin{array}{c}\text { Low } \\
(\text { score }=0)\end{array}$ & $\begin{array}{c}\text { High } \\
(\text { score }=0)\end{array}$ & $\begin{array}{c}\text { Low } \\
(\text { score }=0)\end{array}$ & {$[0,2]$} \\
\hline Mature & $\begin{array}{c}\text { Median } \\
(\text { score }=1)\end{array}$ & $\begin{array}{c}\text { Median } \\
(\text { score }=1)\end{array}$ & $\begin{array}{l}\text { Median } \\
(\text { score }=1)\end{array}$ & $\begin{array}{c}\text { Median } \\
(\text { score }=1)\end{array}$ & {$[3,5]$} \\
\hline Stagnant & $\begin{array}{c}\text { Low } \\
\text { (score }=2)\end{array}$ & $\begin{array}{c}\text { High } \\
\text { (score }=2)\end{array}$ & $\begin{array}{c}\text { Low } \\
(\text { score }=2)\end{array}$ & $\begin{array}{c}\text { High } \\
\text { (score }=2)\end{array}$ & {$[6,8]$} \\
\hline
\end{tabular}

\subsection{Measurement of Performance Discrepancy}

Following previous studies (Audia and Greve, 2006; Bromiley, 1991; Cyert and March, 1992; Lant, 1992; Wiseman and Bromiley,1996; Greve, 2003b; Miller and Chen, 2004; Iyer and Miller, 2008), we use a firm's Return on Assets (ROA) in year $t-2$ as the firm's expected performance $\left(A_{i, t-2}\right)$, and the firm's ROA in year $t-1$ as the firm's actual performance $\left(P_{i, t-1}\right)$. The difference between actual performance and expected performance represents the firm's performance discrepancy. A positive value on $\left(P_{i, t-1}-A_{i, t-2}\right)$ represents positive performance discrepancy; A negative value on $\left(P_{i, t-1}-A_{i, t-2}\right)$ represents negative performance discrepancy.

\subsection{Regression Models}

To test the hypotheses, we develop an Ordinary Least-Squares regression model with the correction of heterogeneity following White (1980). Expressed by Equation (1), a firm's R\&D intensity is regressed on its past performance discrepancy, and a set of control variables. For each stage of business life cycle, we then run Equation (1) based on firms with positive performance discrepancy and those with negative performance discrepancy, respectively.

To support $\mathrm{H}_{1 \mathrm{a}}$, we expect the coefficient on $\delta_{1}$ to be positive for growing firms having positive performance discrepancy. To support $\mathrm{H}_{1 \mathrm{~b}}$, we expect the coefficient on $\delta_{1}$ to be negative for growing firms having negative performance discrepancy if negative performance discrepancy motives managers to exhibit problem-driven search behavior. To support $\mathrm{H}_{1 \mathrm{c}}$, we expect the coefficient on $\delta_{1}$ to be negative for mature firms having positive performance discrepancy. To support $\mathrm{H}_{1 \mathrm{~d}}$, we expect the coefficient on $\delta_{l}$ to be negative for mature firms having negative performance discrepancy. To support $\mathrm{H}_{1 \mathrm{e}}$, we expect the coefficient on $\delta_{l}$ to be negative for stagnant firms having positive performance discrepancy. To support $\mathrm{H}_{1 \mathrm{f}}$, we expect the coefficient on $\delta_{l}$ to be positive for stagnant firms having negative performance discrepancy. 


$$
\begin{aligned}
R D_{i, t} & =\delta_{0}+\delta_{1}\left(P_{i, t-1}-A_{i, t-2}\right)+\delta_{2} S I Z E_{i, t-1}+\delta_{3} L E V_{i, t-1}+\delta_{4} I R D_{i, t-1}+\delta_{5} O I_{i, t-1} \\
& +\delta_{6} F C F_{i, t-1}+\delta_{7} P I H_{i, t-1}+\delta_{8} E I_{i, t-1}+\varepsilon_{i, t}
\end{aligned}
$$

where $R D_{i, t}$ refers to R\&D intensity, which is R\&D expenses divided by net sales revenue for firm $i$ in year $t$. $\left(P_{i, t-1}-\right.$ $A_{i, t-2}$ ) refers to performance discrepancy for firm $i$ in year $t-1$. SIZE $E_{i, t-1}$ refers to nature logarithm of net sales revenue for firm $i$ in year $t-1 . L E V_{i, t-1}$ refers to total liabilities divided by total assets for firm $i$ in year $t-1 . I R D_{i, t-1}$ refers to the median value of industrial R\&D intensity in year $t-1$, based on two-digit Standard Industrial Classification (SIC) code. $O I_{i, t-1}$ refers to earnings before depreciation divided by net sales revenue for firm $i$ in year $t-1 . F C F_{i, t-1}$ refers to cash flow from operations minus fixed assets for firm $i$ in year $t-1$, and then divided by beginning tangible assets. $P I H_{i, t-1}$ refers to the percentage of shareholding by institutional investors for firm $i$ in year $t-l$, which includes government, domestic financial institutes, domestic trust fund, and domestic legal person. $E I_{i, t-l}$ refers to an indicator variable that equals one if the firm is in the electronic industry; zero otherwise. The electronic industry includes firms providing semiconductors, electronic components, telecommunication services, optoelectronic products, or computers and peripherals.

We include a set control variables in Equation (1). We include the firm's net sales $\left(S I Z E_{i, t-1}\right)$ to control for size. Big firms usually have more resources than small firms to support R\&D. Thus, we expect a positive sign on $S I Z E_{i, t-1}$. We include the firm's debt ratio $\left(L E V_{i, t-1}\right)$ to control for leverage. Kobelsky et al. (2008) argue that creditors tend to restrict borrowers' investment if the borrowers raised too many debts. Thus, we expect a negative sign on $L E V_{i, t-1}$. We include industrial R\&D intensity $\left(I R D_{i, t-1}\right)$ to control for industrial innovation. Greve and Taylor (2000) find that paying attention to industrial innovation is helpful for managers to develop new technology. Thus, we expect a positive sign on $I R D_{i, t-1}$. We include the percentage of earnings to sales $\left(O I_{i, t-1}\right)$ in order to control for profitability. Kobelsky et al. (2008) indicate that past performance is a major determinant of investment opportunities. We expect a positive sign on $\mathrm{OI}_{i, t-1}$, because firms with good profitability are more able to engage in R\&D. Following Bushee (1998), we include free cash flow $\left(F C F_{i, t-1}\right)$. Bushee (1998) indicates that firms are more likely to curtail R\&D spending when they have insufficient funds. Thus, we expect a positive sign on $F C F_{i, t-1}$. We include shareholdings of institutional investors $\left(P I H_{i, t-1}\right)$. Bushee (1998) argues that institutional investors pay much attention to firms' short-term performance, which induce managers to reduce R\&D spending. Thus, we expect a negative sign on $P I H_{i, t-1}$. We include an indicator variable that represents the electronic industry $\left(E I_{i, t-1}\right)$. Compared with non-high-tech firms, high-tech firms inherently demand more R\&D. Thus, we expect a positive sign on $E I_{i, t-1}$.

\subsection{Data and Sample Selection}

The preliminary sample contains all Taiwanese publicly held companies in Taiwan Economic Journal database during the period from 2001 to 2010 . We focus on the firms using the calendar year as their fiscal year. We remove any observations that lack a value needed to construct the regression variables, as well as firms in the financial services industry. Table 2 summarizes the sample selection procedure. There are preliminarily 7,434 firm-years. The selection criteria yield a sample of 4,067 observations, corresponding to 497 firms.

Table 2. Sample selection procedure

\begin{tabular}{ll}
\hline Sample Selection Procedure & \\
\hline Preliminary sample & 7,434 \\
Less: & $(41)$ \\
Firms with non-calendar year & $(2,346)$ \\
Missing financial data & $(980)$ \\
Missing data for the calculation of business life cycle & 4,067 \\
Final sample &
\end{tabular}

Table 3 reports the sample distribution by industry based on two-digit SIC code. Among the industries that is well represented is Electronic industry (SIC 13), which contains 2,516 (61.86\%) observations. Table 4 reports the sample distribution by the stages of business life cycle. Most of the firms are mature firms. There are 941 firm-years being classified into the growth stage, 2,207 firm-years being classified into the mature stage, and 919 firm-years being classified into the stagnant stage. 
Table 3. Sample distribution by industry

\begin{tabular}{ccccc}
\hline Two-Digit SIC Code & Industry Name & Observations & Firm-Years & \% of Firm-Years \\
\hline 01 & Cement & 4 & 26 & 0.64 \\
02 & Food & 12 & 104 & 2.56 \\
03 & Plastic & 14 & 109 & 2.68 \\
04 & Textile & 27 & 242 & 5.95 \\
05 & Electric Machinery & 33 & 295 & 7.25 \\
06 & Electrics \& Cable & 7 & 68 & 1.67 \\
07 & Chemistry and Biology & 31 & 234 & 5.75 \\
08 & Glass \& Ceramic & 4 & 39 & 0.96 \\
09 & Paper Products & 4 & 39 & 0.96 \\
10 & Iron \& Steel & 11 & 90 & 2.21 \\
11 & Rubber & 9 & 62 & 1.52 \\
12 & Automobile & 2 & 24 & 0.59 \\
13 & Electronic & 312 & 2,516 & 61.86 \\
14 & Construction & 5 & 31 & 0.76 \\
15 & Transportation & 1 & 6 & 0.15 \\
18 & General Merchandise & 2 & 15 & 0.37 \\
20 & Other & 18 & 159 & 3.91 \\
23 & Gasoline & 1 & 8 & 0.20 \\
\hline
\end{tabular}

Table 4. Sample distribution by stages of business life cycle

\begin{tabular}{|c|c|c|c|c|c|c|}
\hline $\begin{array}{l}\text { Two-Digit SIC } \\
\text { Code }\end{array}$ & Industry Name & $\begin{array}{c}\text { Growth } \\
\text { Stage }\end{array}$ & $\begin{array}{l}\text { Mature } \\
\text { Stage }\end{array}$ & $\begin{array}{l}\text { Stagnant } \\
\text { Stage }\end{array}$ & Total & $\%$ \\
\hline 01 & Cement & 0 & 14 & 12 & 26 & 0.64 \\
\hline 02 & Food & 5 & 51 & 48 & 104 & 2.56 \\
\hline 03 & Plastic & 5 & 66 & 38 & 109 & 2.68 \\
\hline 04 & Textile & 20 & 126 & 96 & 242 & 5.95 \\
\hline 05 & Electric Machinery & 33 & 160 & 102 & 295 & 7.25 \\
\hline 06 & Electrics \& Cable & 4 & 35 & 29 & 68 & 1.67 \\
\hline 07 & Chemistry and Biology & 33 & 116 & 85 & 234 & 5.75 \\
\hline 08 & Glass \& Ceramic & 2 & 27 & 10 & 39 & 0.96 \\
\hline 09 & Paper Products & 0 & 25 & 14 & 39 & 0.96 \\
\hline 10 & Iron \& Steel & 6 & 45 & 39 & 90 & 2.21 \\
\hline 11 & Rubber & 0 & 48 & 14 & 62 & 1.52 \\
\hline 12 & Automobile & 0 & 10 & 14 & 24 & 0.59 \\
\hline 13 & Electronics & 806 & 1,356 & 354 & 2,516 & 61.86 \\
\hline 14 & Construction & 4 & 15 & 12 & 31 & 0.76 \\
\hline 15 & Transportation & 0 & 5 & 1 & 6 & 0.15 \\
\hline 18 & General Merchandise & 1 & 8 & 6 & 15 & 0.37 \\
\hline 20 & Other & 20 & 95 & 44 & 159 & 3.91 \\
\hline \multirow[t]{2}{*}{23} & Gasoline & 2 & 5 & 1 & 8 & 0.20 \\
\hline & Total & 941 & 2,207 & 919 & 4,067 & 100 \\
\hline
\end{tabular}




\section{Empirical Results}

\subsection{Descriptive Statistics and Correlation Analysis}

Table 5 reports descriptive statistics. On average, sample firms' R\&D expenditures $(R D)$ are $3.138 \%$ of their sales. The median value, standard deviation, minimum value, and maximum value of $R D$ are $1.890 \%, 4.275,0.000 \%$, and $44.810 \%$, respectively. These results suggest that R\&D expenditures vary with firms. The mean value of sales growth $(S G)$ is $13.810 \%$, which is higher than its median value $(9.300 \%)$. This indicates that $S G$ is right-skewed. There is large variance of $S G$ among firms ( $\mathrm{STD}=31.564)$. The mean and median values of dividend payouts $(D P)$ are $0.442 \%$ and $0.367 \%$, respectively. The mean and median values of capital expenditure $(C E V)$ are $0.029 \%$ and $0.007 \%$ of firms' market value, respectively, suggesting that $C E V$ exhibits right-skewed. The mean value of firm age $(A G E)$ is 24.391 years. The mean value of the total score of business life cycle (LIFECYCLE) is 3.999, indicating that the sample firms on average are mature firms. The mean and median values of performance discrepancy $(P-A)$ are $-0.548 \%$ and $-0.329 \%$, respectively, indicating that the sample firms on average have negative performance discrepancy. The mean and median values of the $\log$ of net sales (SIZE) are 15.527 and 15.328, respectively. On average, sample firms raise $41.74 \%$ debts $(L E V)$ of their assets. The mean and median values of industrial $\mathrm{R} \& \mathrm{D}$ intensity $(I R D)$ are $0.022 \%$ and $0.021 \%$, respectively. The mean and median values of profitability $(O I)$ are $0.125 \%$ and $0.105 \%$, respectively. The mean and median values of free cash flow $(F C F)$ are $0.066 \%$ and $0.074 \%$, respectively. The mean and median values of institutional investors' shareholding $(P I H)$ are $23.414 \%$ and $19.110 \%$, respectively.

Table 5. Descriptive statistics

\begin{tabular}{lrrrrr}
\hline \multicolumn{1}{c}{ Variable } & Mean & STD & Median & Minimum & Maximum \\
\hline$R D(\%)$ & 3.138 & 4.275 & 1.890 & 0.000 & 44.810 \\
$S G(\%)$ & 13.810 & 31.564 & 9.300 & -79.480 & 288.420 \\
$D P(\%)$ & 0.442 & 1.839 & 0.367 & -26.862 & 74.532 \\
$C E V(\%)$ & 0.029 & 0.155 & 0.007 & -1.557 & 2.570 \\
$A G E$ & 24.391 & 12.276 & 22.653 & 0.711 & 59.864 \\
LIFECYCLE & 3.999 & 1.849 & 4.000 & 0.000 & 8.000 \\
$(P-A)(\%)$ & -0.548 & 7.240 & -0.329 & -63.675 & 87.970 \\
$S I Z E$ & 15.527 & 1.437 & 15.328 & 10.962 & 21.396 \\
$L E V(\%)$ & 41.738 & 15.683 & 42.410 & 4.170 & 98.590 \\
$I R D(\%)$ & 0.022 & 0.016 & 0.021 & 0.000 & 0.067 \\
$O I(\%)$ & 0.125 & 0.125 & 0.105 & -1.109 & 0.713 \\
$F C F(\%)$ & 0.066 & 0.148 & 0.074 & -1.364 & 0.866 \\
$P I H(\%)$ & 23.414 & 18.465 & 19.110 & 0.000 & 99.990 \\
$E I$ & 0.566 & 0.496 & 1.000 & 0.000 & 1.000 \\
\hline
\end{tabular}

Table 6 reports the correlation analysis among variables. The upper right of the Table reports Spearman correlation coefficients, and the lower left of the Table reports Pearson correlation coefficients. The absolute values of correlation coefficient among the variables are below 0.7. In addition, the unreported test of Variance Inflation Factors (VIF) indicates that the VIF values of all the variables are below 10. These results indicate that there is little evidence on potential multi-collinearity. The Pearson correlation coefficient between $I R D$ and $E I$ is $0.589(\mathrm{P}<0.01)$, indicating that the R\&D intensity of electronic firms are correlated to past industrial R\&D intensity. 
Table 6. Correlation analysis

\begin{tabular}{|c|c|c|c|c|c|c|c|c|c|c|c|c|c|}
\hline & $R D$ & $S G$ & $D P$ & CEV & $A G E$ & $(P-A)$ & $S Z Z E$ & $L V E$ & $I R D$ & OI & $F C F$ & PIH & El \\
\hline$R D$ & & $=0.052^{* * *}$ & -0.023 & $0.034^{* 4}$ & $-0.367^{* * *}$ & $-0.084 * *$ & $-0.259^{\circ \cdots *}$ & $0.300^{* * 4}$ & $0.596^{\circ * *}$ & $0.218^{* * *}$ & $0.143^{* * *}$ & $-0.125^{* * *}$ & $0.429^{* * *}$ \\
\hline$S G$ & $-0.045^{* * 4}$ & & $0.032^{* *}$ & $335^{* *}$ & -0.188 *** & $0.353^{* * *}$ & $0.087^{* * *}$ & $0.072 * *$ & $0.026^{*}$ & $0.302^{* * *}$ & $-0.135 * *$ & $-0.035 *$ & $0.110^{* * *}$ \\
\hline$D P$ & -0.006 & .0 .026 & & $0.052^{* * 4}$ & $0.113^{* * *}$ & $0.044^{* t *}$ & $0.159^{\circ \cdots+}$ & $-0.228^{c k t}$ & -0.015 & $0.216^{* t * 4}$ & $0.2200^{*+*}$ & $0.109^{*+*}$ & $-0.077^{* 0}$ \\
\hline CEV & -0.007 & $0.242^{* t 0}$ & 0.007 & & $-0.125^{* * t}$ & $-0.079^{* 6 *}$ & 0.011 & 0.017 & $0.052^{\circ .0 *}$ & $0.275^{* k+4}$ & -1). $443^{* * *}$ & -0.011 & $0.121 \cdots$ \\
\hline$A G E$ & $-0.295^{* * *}$ & $-0.204^{* * *}$ & 0.018 & $-0.090^{* * *}$ & & $0.057^{* * *}$ & $0.135^{* * *}$ & $0.113^{* * *}$ & $-0.453^{* * *}$ & $-0.205^{* * *}$ & $-0.051^{* * *}$ & 0.016 & $-0.507^{* * *}$ \\
\hline$(P-A)$ & $-0.075 * * *$ & $0.308^{* * *}$ & -0.020 & 0.014 & $0.039^{* *}$ & & 0.003 & -0.020 & $-0.050^{* * *}$ & $0.167^{* * *}$ & $0.126^{* * *}$ & -0.020 & $-0.052^{* * *}$ \\
\hline SIZE & $-0.185^{* * *}$ & $0.068^{* * *}$ & 0.023 & -0.009 & $0.142^{* * *}$ & 0.003 & & $0.338^{* * * *}$ & $-0.0600^{* * *}$ & $-0.122^{* * *}$ & $0.054 * * *$ & $0.229^{* * *}$ & 0.020 \\
\hline LEV & $-0.286^{* * *}$ & $0.045 *$ & $-0.046^{* * *}$ & -0.024 & $0.114^{* * *}$ & -0.023 & $0.301^{* * *}$ & & $-0.181^{* * 0}$ & $-0.391^{* * *}$ & $-0.305^{* * *}$ & 0.016 & $-0.106^{* 2 *}$ \\
\hline$I R D$ & $0.457^{* * 0}$ & $0.050^{* * *}$ & -0.001 & 0.020 & $-4.430^{* * *}$ & $-0.034^{* t}$ & -0.014 & $-0.204^{* 28}$ & & $0.212^{* * *}$ & $0.160^{* * * *}$ & $-0.034^{* *}$ & $0.639^{* * x}$ \\
\hline OI & $0.078 * 3 *$ & $0.272^{* * *}$ & 0.020 & $0.247^{* * 4}$ & $-0.195^{* * *}$ & $0.182^{* * *}$ & 0.005 & $-0,370^{* * * *}$ & $0.243^{* * *}$ & & $0.300^{k * *}$ & $0.043^{* * *}$ & $0.193^{* * *}$ \\
\hline$F C F$ & $0.109^{* * *}$ & $-0.199^{* * *}$ & 0.020 & $-0.507^{* * 4}$ & $-0.0131^{* *}$ & $0.069^{* * *}$ & $0.063^{* * *}$ & $-0.254^{* * 4}$ & $0.163^{* * *}$ & $0.250^{* * * *}$ & & $0.086^{* * *}$ & $0.095^{* * *}$ \\
\hline PIH & $-0.104^{* * *}$ & -0.021 & -0.006 & 0.007 & $-1) .032 * *$ & -0.011 & $0.211^{* * 4}$ & 0.014 & -0.025 & $0,077^{* * *}$ & $0.075^{* * 4}$ & & $-0.051^{* 4 *}$ \\
\hline El & $0.290^{\circ 40}$ & $0.129^{\circ 4.4}$ & -0.025 & $0.077^{* 4 *}$ & $-0.516^{* * 4}$ & $-0.039^{4 * 4}$ & $0.043^{0.4}$ & $-0,109^{* 4.4}$ & $0.589^{4+4}$ & $0.188^{456}$ & $0.065^{.44}$ & $-0.056^{4+4}$ & \\
\hline
\end{tabular}

1. The upper right of the Table reports Spearman correlation coefficients; the lower left of the Table reports Pearson correlation coefficients.

2. *, **, and $* * *$ represent significance levels of $0.10,0.05$, and 0.01 , respectively.

\subsection{Empirical Results}

Table 7 shows how performance discrepancy and business life cycle jointly affect managers' R\&D decisions. Consistent with $\mathrm{H}_{1 \mathrm{a}}$, the coefficient on $\left(P_{i, t-1}-A_{i, t-2}\right)$ is significantly positive for growing firms experiencing positive performance discrepancy, which indicates that higher level of positive performance discrepancy motives managers of growing firms to increase R\&D expenditure. The negative but statistically insignificant coefficient on $\left(P_{i, t-1}-A_{i, t-2}\right)$ for growing firms experiencing negative performance discrepancy fails to support $\mathrm{H}_{1 \mathrm{~b}}$. The coefficient on $\left(P_{i, t-1}-A_{i, t-2}\right)$ for mature firms experiencing positive performance discrepancy is positive but statistically insignificant, which fails to support $\mathrm{H}_{1 \mathrm{c}}$. Consistent with $\mathrm{H}_{1 \mathrm{~d}}$, the coefficient on $\left(P_{i, t-1}-A_{i, t-2}\right)$ is significantly negative for mature firms experiencing negative performance discrepancy, which indicates that more negative performance discrepancy motives managers of mature firms to increase $\mathrm{R} \& \mathrm{D}$ expenditure. The coefficients on $\left(P_{i, t-1}-A_{i, t-2}\right)$ are positive but statistically insignificant for stagnant firms experiencing positive performance discrepancy. The coefficients on $\left(P_{i, t-1}\right.$ $\left.-A_{i, t-2}\right)$ are negative but statistically insignificant for stagnant firms experiencing negative performance discrepancy. Overall, the findings in Table 7 support $\mathrm{H}_{1 \mathrm{a}}$ and $\mathrm{H}_{1 \mathrm{~d}}$. Consistent with the expectations, more $\mathrm{R} \& \mathrm{D}$ expenditures are associated with lower leverage ( $L E V)$ and higher level of R\&D in the industry (IRD).

Table 7. The impact of business life cycle and performance discrepancy on R\&D expenditures

\begin{tabular}{|c|c|c|c|c|c|c|c|c|c|c|c|c|}
\hline$R D_{i, 1}=\delta_{0}$ & $P_{u-1}-A_{L u}$ & $-2)+\delta_{2} S I Z I$ & $E_{2-1}+\delta_{3} L t$ & $V_{u-1}+\delta_{4} l$ & $D_{L-1}+\delta_{5} O$ & $b_{1,-1}+\delta_{b} F C$ & $F_{i, 1-1}+\delta_{7} P$ & $H_{z-1-1}+\delta_{8} E$ & $I_{i, t-1}+\varepsilon_{i, t}$ & & & 1) \\
\hline & Levels: & $\delta_{0}$ & $\delta_{1}$ & $\delta_{2}$ & $\delta_{3}$ & $\delta_{4}$ & $\delta_{5}$ & $\delta_{6}$ & $\delta_{7}$ & $\delta_{8}$ & $\operatorname{Adj} R^{2}$ & $N$ \\
\hline I. Growth Stage: & & & & & & & & & & & & \\
\hline Performance & Positive & $\begin{array}{l}7.042 \\
(0.004)^{* * *}\end{array}$ & $\begin{array}{l}0.046 \\
(0.035)^{* *}\end{array}$ & $\begin{array}{l}-0.184 \\
(0.284)\end{array}$ & $\begin{array}{l}-0.068 \\
(0.000)^{* * *}\end{array}$ & $\begin{array}{l}76.910 \\
(0.000)^{* * *}\end{array}$ & $\begin{array}{l}-1.243 \\
(0.446)\end{array}$ & $\begin{array}{l}1.129 \\
(0.153)\end{array}$ & $\begin{array}{l}-0.014 \\
(0.029)^{* *}\end{array}$ & $\begin{array}{l}0.317 \\
(0.416)\end{array}$ & 0.221 & 485 \\
\hline Discrepancy & Negative & $\begin{array}{l}11.183 \\
(0.000)^{* * * t}\end{array}$ & $\begin{array}{l}-0.036 \\
(0.433)\end{array}$ & $\begin{array}{l}-0.492 \\
(0.009)^{* * *}\end{array}$ & $\begin{array}{l}-0,061 \\
(0,000)^{* * *}\end{array}$ & $\begin{array}{l}123.701 \\
(0.000)^{* *=*}\end{array}$ & $\begin{array}{l}-1.134 \\
(0.645)\end{array}$ & $\begin{array}{l}-0.658 \\
(0.586)\end{array}$ & $\begin{array}{l}.0 .012 \\
(0.183)\end{array}$ & $\begin{array}{l}-0.164 \\
(0.743)\end{array}$ & 0.196 & 456 \\
\hline II. Mature Stage: & & & & & & & & & & & & \\
\hline Performance & Positive & $\begin{array}{l}5.948 \\
(0.000)^{4 \times 4}\end{array}$ & $\begin{array}{l}0.010 \\
(0.707)\end{array}$ & $\begin{array}{l}-0.203 \\
(0.020)^{*=-}\end{array}$ & $\begin{array}{l}-0.045 \\
(0.000)^{* * *}\end{array}$ & $\begin{array}{l}111.306 \\
(0.000)^{\text {s.t. }}\end{array}$ & $\begin{array}{l}-3.220 \\
(0.030)^{* t}\end{array}$ & $\begin{array}{l}3.306 \\
(0.001)^{* * *}\end{array}$ & $\begin{array}{l}0.007 \\
(0.155)\end{array}$ & $\begin{array}{l}-0.100 \\
(0.662)\end{array}$ & 0.328 & 970 \\
\hline Discrepancy & Negative & $\begin{array}{l}9.699 \\
(0.000)^{* * *}\end{array}$ & $\begin{array}{l}-0.073 \\
(0.024)^{* *}\end{array}$ & $\begin{array}{l}-0.348 \\
(0.000)^{* * *}\end{array}$ & $\begin{array}{l}-0.067 \\
(0.0000)^{* * * *}\end{array}$ & $\begin{array}{l}106.340 \\
(0.000)^{* * *}\end{array}$ & $\begin{array}{l}-5.221 \\
(0.034)^{* *}\end{array}$ & $\begin{array}{l}1.368 \\
(0.163)\end{array}$ & $\begin{array}{l}-4.049 \\
(0.000)^{* * * *}\end{array}$ & $\begin{array}{l}1.532 \\
(0.126)\end{array}$ & 0.291 & 1237 \\
\hline III. Stagnant Stage & & & & & & & & & & & & \\
\hline Performance & Positive & $\begin{array}{l}3.004 \\
(0.024)^{* *}\end{array}$ & $\begin{array}{l}0.120 \\
(0.258)\end{array}$ & $\begin{array}{l}-0.137 \\
(0.109)\end{array}$ & $\begin{array}{l}-0,021 \\
(0.009)^{* * *}\end{array}$ & $\begin{array}{l}104.275 \\
(0.000)^{* * *}\end{array}$ & $\begin{array}{l}0.097 \\
(0.934)\end{array}$ & $\begin{array}{l}0.590 \\
(0.710)\end{array}$ & $\begin{array}{l}-0,005 \\
(0.360)\end{array}$ & $\begin{array}{l}-0.155 \\
(0.533)\end{array}$ & 0.467 & 428 \\
\hline Discrepancy & Negative & $\begin{array}{l}7.879 \\
(0.000)^{* * *}\end{array}$ & $\begin{array}{l}-0.113 \\
(0.150)\end{array}$ & $\begin{array}{l}-0.314 \\
(0.004)^{* * t}\end{array}$ & $\begin{array}{l}-0.049 \\
(0.000)^{* * *}\end{array}$ & $\begin{array}{l}94.592 \\
(0.000)^{* 1 *=}\end{array}$ & $\begin{array}{l}-3.976 \\
(0.117)\end{array}$ & $\begin{array}{l}0.816 \\
(0.819)\end{array}$ & $\begin{array}{l}-0.023 \\
(0.010)^{*=*}\end{array}$ & $\begin{array}{l}0.668 \\
(0.050)^{* *}\end{array}$ & 0.281 & 491 \\
\hline
\end{tabular}

$*$,**, and *** represent significance levels of $0.10,0.05$, and 0.01 , respectively. The numbers in the parentheses represent p-value. 


\subsection{Additional Analysis}

Tables $8,9,10$, and 11 report the regression results when sample firms' business life cycle is identified according to each of the life cycle descriptors. Table 8 reports the results if the business life cycle is identified according to a firm's sales growth. The results in Table 8 are similar to the main findings. Consistent with $\mathrm{H}_{1 \mathrm{a}}$, the positive coefficient on $\left(P_{i, t-1}-A_{i, t-2}\right)$ indicates that managers of growing firms increase $\mathrm{R} \& \mathrm{D}$ expenditure when they perceive positive performance discrepancy. Consistent with $\mathrm{H}_{1 \mathrm{~d}}$, the negative coefficient on $\left(P_{i, t-1}-A_{i, t-2}\right)$ indicates that that managers of mature firms increase $\mathrm{R} \& \mathrm{D}$ expenditure when they are disappointed with corporate performance, implying problem-driven search behavior. The positive but statistically insignificant coefficient on $\left(P_{i, t-1}-A_{i, t-2}\right)$ for growing firms experiencing negative performance discrepancy fails to support $\mathrm{H}_{1 \mathrm{~b}}$. The coefficient on $\left(P_{i, t-1}-A_{i, t-2}\right)$ for mature firms experiencing positive performance discrepancy is negative but statistically insignificant, which fails to support $\mathrm{H}_{1 \mathrm{c}}$. The coefficient on $\left(P_{i, t-1}-A_{i, t-2}\right)$ for stagnant firms experiencing negative performance discrepancy is significantly negative at ten percent significance level. A possible explanation for this is that managers of stagnant firms with low sales growth still have problem-driven search behavior when they experience negative performance discrepancy. The results remain similar when business life cycle is identified according to dividend payout ratio, capital expenditure, and firm age, respectively, as reported in Tables 9, 10, and 11.

Table 8. Regression results using sales growth to identify the stages of business life cycle

\begin{tabular}{|c|c|c|c|c|c|c|c|c|c|c|c|c|}
\hline \multicolumn{11}{|c|}{$R D_{i j}=\delta_{0}+\delta_{1}\left(P_{i, t-1}-A_{i, t-2}\right)+\delta_{2} S I Z E_{i, j-1}+\delta_{3} L E V_{i t-1}+\delta_{1} I R D_{i t-1}+\delta_{5} O I_{i, j-1}+\delta_{6} F C F_{i j-1}+\delta_{T} P I H_{i, j-1}+\delta_{i} E I_{i, t-1}+\varepsilon_{i s}$} & \multicolumn{2}{|c|}{ (1) } \\
\hline & Levels & $\delta_{0}$ & $\delta_{1}$ & $\delta_{2}$ & $\delta_{3}$ & $\delta_{4}$ & $\delta_{5}$ & $\delta_{6}$ & $\delta_{7}$ & $\delta_{8}$ & $A d i R^{2}$ & $N$ \\
\hline \multicolumn{13}{|l|}{ L. Growth Stage: } \\
\hline Performance & Positive & $\begin{array}{l}5.003 \\
(0.001)^{* * *}\end{array}$ & $\begin{array}{l}0.039 \\
(0.050)^{* *}\end{array}$ & $\begin{array}{l}-0.146 \\
(0.150)\end{array}$ & $\begin{array}{l}-0.049 \\
(0.000)^{* 4 *}\end{array}$ & $\begin{array}{l}91.012 \\
(0.000)^{* 4 *}\end{array}$ & $\begin{array}{l}0.545 \\
(0.687)\end{array}$ & $\begin{array}{l}1.712 \\
(0.012)^{* 4 *}\end{array}$ & $\begin{array}{l}-0.011 \\
(0.036)^{2 *}\end{array}$ & $\begin{array}{l}0.096 \\
(0.698)\end{array}$ & 0.292 & 855 \\
\hline Discrepancy & Negative & $\begin{array}{l}8.289 \\
(0.002)^{* * *}\end{array}$ & $\begin{array}{l}0.019 \\
(0.683)\end{array}$ & $\begin{array}{l}-0.314 \\
(0.056)^{*}\end{array}$ & $\begin{array}{l}-0.062 \\
(0.000)^{* * *}\end{array}$ & $\begin{array}{l}138.565 \\
(0.000)^{* * * *}\end{array}$ & $\begin{array}{l}-0.344 \\
(0.884)\end{array}$ & $\begin{array}{l}0.252 \\
(0.733)\end{array}$ & $\begin{array}{l}-0.009 \\
(0.181)\end{array}$ & $\begin{array}{l}-0.522 \\
(0.202)\end{array}$ & 0.288 & 501 \\
\hline \multicolumn{13}{|l|}{ IL. Mature Stage: } \\
\hline Performance & Positive & $\begin{array}{l}5,155 \\
(0.000)^{* * 4}\end{array}$ & $\begin{array}{l}-0.004 \\
(0.925)\end{array}$ & $\begin{array}{l}-0.138 \\
(0.184)\end{array}$ & $\begin{array}{l}-0.051 \\
(0.000)^{* * *}\end{array}$ & $\begin{array}{l}124.885 \\
(0.000)^{* * *}\end{array}$ & $\begin{array}{l}-3.890 \\
(0.020)^{* * *}\end{array}$ & $\begin{array}{l}1.314 \\
(0.248)\end{array}$ & $\begin{array}{l}-0.010 \\
(0.064)^{*}\end{array}$ & $\begin{array}{l}0.041 \\
(0.881)\end{array}$ & 0.393 & 613 \\
\hline Discrepancy & Negutive & $\begin{array}{l}7.589 \\
(0.000)^{* * *}\end{array}$ & $\begin{array}{l}-0.089 \\
(0.012)^{* *}\end{array}$ & $\begin{array}{l}-0.294 \\
(0.003)^{* * *}\end{array}$ & $\begin{array}{l}-0.051 \\
(0.000)^{* * *}\end{array}$ & $\begin{array}{l}87.100 \\
(0.000)^{* * *}\end{array}$ & $\begin{array}{l}0.676 \\
(0.667)\end{array}$ & $\begin{array}{l}0.594 \\
(0.687)\end{array}$ & $\begin{array}{l}-0.020 \\
(0.003)^{* * *}\end{array}$ & $\begin{array}{l}0.598 \\
(0.010)^{* *}\end{array}$ & 0.320 & 743 \\
\hline \multicolumn{13}{|l|}{ III. Stagnant Stage: } \\
\hline Performance & Positive & $\begin{array}{l}6.820 \\
(0.006)^{* * *}\end{array}$ & $\begin{array}{l}0.086 \\
(0.170)\end{array}$ & $\begin{array}{l}-0.335 \\
(0,021)^{4 *}\end{array}$ & $\begin{array}{l}-0.029 \\
(0.016)^{44}\end{array}$ & $\begin{array}{l}83.437 \\
(0.000)^{+4 * 4}\end{array}$ & $\begin{array}{l}-2.195 \\
(0.203)\end{array}$ & $\begin{array}{l}0.637 \\
(0.715)\end{array}$ & $\begin{array}{l}-10.002 \\
(0.822)\end{array}$ & $\begin{array}{l}0.588 \\
(0.056)^{*}\end{array}$ & 0.271 & 415 \\
\hline Discrepancy & Negative & $\begin{array}{l}11.091 \\
(0.000)^{* * *}\end{array}$ & $\begin{array}{l}-0.066 \\
(0.073)^{*}\end{array}$ & $\begin{array}{l}-0.441 \\
(0.000)^{* * *}\end{array}$ & $\begin{array}{l}-0.066 \\
(0.000)^{* * *}\end{array}$ & $\begin{array}{l}109.057 \\
(0.000)^{* * *}\end{array}$ & $\begin{array}{l}-6.396 \\
(0.020)^{* *}\end{array}$ & $\begin{array}{c}-1.343 \\
(0.461)\end{array}$ & $\begin{array}{l}-0.025 \\
(0.000)^{* * *}\end{array}$ & $\begin{array}{l}0.647 \\
(0.039)^{* *}\end{array}$ & 0.243 & 941) \\
\hline
\end{tabular}

$*, * *$, and $* * *$ represent significance levels of $0.10,0.05$, and 0.01 , respectively. The numbers in the parentheses represent p-value.

Table 9. Regression results using dividend payout ratio to identify the stages of business life cycle

\begin{tabular}{|c|c|c|c|c|c|c|c|c|c|c|c|c|}
\hline \multicolumn{11}{|c|}{$R D_{i, j}=\delta_{0}+\delta_{1}\left(P_{i, j-1}-A_{i, j-2}\right)+\delta_{2} S I Z E_{i, j-1}+\delta_{3} L E V_{i, j-1}+\delta_{2} I R D_{i, j-1}+\delta_{5} O I_{i, j-1}+\delta_{i} F C F_{i, i-1}+\delta_{7} P I H_{i,-1}+\delta_{3} E I_{i, j-1}+\varepsilon_{i, j}$} & \multicolumn{2}{|c|}{ (1) } \\
\hline & Levels & $\delta_{0}$ & $\delta_{1}$ & $\delta_{2}$ & $\delta_{3}$ & $\delta_{4}$ & $\delta_{3}$ & $\delta_{6}$ & $\delta 7$ & $\delta_{8}$ & $A d j R^{2}$ & N \\
\hline \multicolumn{13}{|l|}{ 1. Growth Stage: } \\
\hline Performance & Positive & $\begin{array}{l}6.549 \\
(0.006)^{* * *}\end{array}$ & $\begin{array}{l}0.035 \\
(0.066)^{*}\end{array}$ & $\begin{array}{l}-0.272 \\
(0.087)^{*}\end{array}$ & $\begin{array}{l}-0.035 \\
(0.003)^{* * *}\end{array}$ & $\begin{array}{l}103.788 \\
(0.000)^{* k-k}\end{array}$ & $\begin{array}{l}0.108 \\
(0.948)\end{array}$ & $\begin{array}{l}0.410 \\
(0.663)\end{array}$ & $\begin{array}{l}-0.009 \\
(0.234)\end{array}$ & $\begin{array}{l}-0.064 \\
(0.864)\end{array}$ & 0.229 & 570 \\
\hline Discrepancy & Negative & $\begin{array}{l}11.633 \\
(0.006)^{* * *}\end{array}$ & $\begin{array}{l}-0.037 \\
(0.311)\end{array}$ & $\begin{array}{l}-0.529 \\
(0.003)^{* * *}\end{array}$ & $\begin{array}{l}-0,056 \\
(0,000)^{* * *}\end{array}$ & $\begin{array}{l}121.586 \\
(0.000)^{\text {*a* }}\end{array}$ & $\begin{array}{l}-6.391 \\
(0.035)^{* *}\end{array}$ & $\begin{array}{l}-0.658 \\
(0.585)\end{array}$ & $\begin{array}{l}0.010 \\
(0.242)\end{array}$ & $\begin{array}{l}0.684 \\
(0.096)^{*}\end{array}$ & 0.217 & 786 \\
\hline \multicolumn{13}{|l|}{ II. Mature Stage: } \\
\hline Performance & Positive & $\begin{array}{l}6.917 \\
(0.000)^{* * *}\end{array}$ & $\begin{array}{l}0.012 \\
(0.751)\end{array}$ & $\begin{array}{l}-0.243 \\
(0.0000)^{* * *}\end{array}$ & $\begin{array}{l}-0,048 \\
(0,000)^{* * 4}\end{array}$ & $\begin{array}{l}80.813 \\
(0.000)^{4 * *}\end{array}$ & $\begin{array}{l}-2.359 \\
(0.064)^{*}\end{array}$ & $\begin{array}{l}1.969 \\
(0.010)^{* *}\end{array}$ & $\begin{array}{l}-0.010 \\
(0.060)^{2}\end{array}$ & $\begin{array}{l}0.187 \\
(0.396)\end{array}$ & 0.304 & 687 \\
\hline Discrepancy & Negative & $\begin{array}{l}7.736 \\
(0,000)^{* * 4}\end{array}$ & $\begin{array}{l}-0.062 \\
(0.135)\end{array}$ & $\begin{array}{l}-0.279 \\
(0.000)^{* * *}\end{array}$ & $\begin{array}{l}-0.053 \\
(0.000)^{4 * 6}\end{array}$ & $\begin{array}{l}82.107 \\
(0.000)^{4 * 4}\end{array}$ & $\begin{array}{l}-0.540 \\
(0.697)\end{array}$ & $\begin{array}{l}0.483 \\
(0.661)\end{array}$ & $\begin{array}{l}-0.014 \\
(0.006)^{40.4}\end{array}$ & $\begin{array}{l}0.101 \\
(0.650)\end{array}$ & 0.321 & 669 \\
\hline \multicolumn{13}{|l|}{ III. Stagnant Stage: } \\
\hline Performance & Positive & $\begin{array}{l}1.917 \\
(0.227)\end{array}$ & $\begin{array}{l}0.140 \\
(0.205)\end{array}$ & $\begin{array}{l}-0.028 \\
(0.792)\end{array}$ & $\begin{array}{l}-0.044 \\
(0.000)^{\bullet * *}\end{array}$ & $\begin{array}{l}111.216 \\
(0.000)^{4+4}\end{array}$ & $\begin{array}{l}-0.142 \\
(0.934)\end{array}$ & $\begin{array}{l}3.376 \\
(0.011)^{e 4 *}\end{array}$ & $\begin{array}{l}-0.007 \\
(0.272)\end{array}$ & $\begin{array}{l}0.463 \\
(0.074)^{*}\end{array}$ & 0.449 & 626 \\
\hline Discrepancy & Negative & $\begin{array}{l}7.216 \\
(0.000)^{* * 4}\end{array}$ & $\begin{array}{l}-0.151 \\
(0.009)^{* \ldots *}\end{array}$ & $\begin{array}{l}-0.248 \\
(0.004)^{* \cdots *}\end{array}$ & $\begin{array}{l}-0,065 \\
(0,000)^{4 * 4}\end{array}$ & $\begin{array}{l}106.455 \\
(0.000)^{* * *}\end{array}$ & $\begin{array}{c}-0.194 \\
(0.929)\end{array}$ & $\begin{array}{l}0.737 \\
(0.526)\end{array}$ & $\begin{array}{l}-0.033 \\
(0.000) * * *\end{array}$ & $\begin{array}{l}0.666 \\
(0.019)^{* 4}\end{array}$ & 0.355 & 729 \\
\hline
\end{tabular}

$*, * *$, and $* * *$ represent significance levels of $0.10,0.05$, and 0.01 , respectively. The numbers in the parentheses represent p-value. 
Table 10. Regression results using capital expenditure to identify the stages of business life cycle

\begin{tabular}{|c|c|c|c|c|c|c|c|c|c|c|c|c|}
\hline \multicolumn{11}{|c|}{ 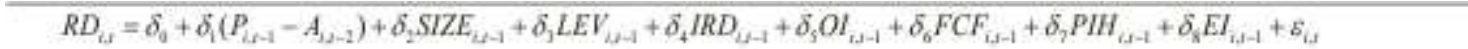 } & \multicolumn{2}{|c|}{ (1) } \\
\hline & Levels & $\dot{\delta}_{0}$ & $\delta_{1}$ & $\delta_{2}$ & $\delta_{3}$ & $\delta_{4}$ & $\delta_{5}$ & $\delta_{6}$ & $\delta_{3}$ & $\hat{\delta}_{\mathrm{B}}$ & $A d j R^{2}$ & $N$ \\
\hline \multicolumn{13}{|l|}{ 1. Growth Stage: } \\
\hline Performance & Positive & $\begin{array}{l}6.478 \\
(0.001)^{* * *}\end{array}$ & $\begin{array}{l}0.059 \\
(0.039)^{4 *}\end{array}$ & $\begin{array}{l}-0.269 \\
(0.053)^{*}\end{array}$ & $\begin{array}{l}-0.031 \\
(0.013)^{* *}\end{array}$ & $\begin{array}{l}71.021 \\
(0.0000 * * 4\end{array}$ & $\begin{array}{l}0.801 \\
(0.608)\end{array}$ & $\begin{array}{l}0.003 \\
(0.997)\end{array}$ & $\begin{array}{l}-0.012 \\
(0.020)^{\star *}\end{array}$ & $\begin{array}{l}0.067 \\
(0.824)\end{array}$ & 0.184 & 544 \\
\hline Discrepancy & Negative & $\begin{array}{l}7,602 \\
(0.000)^{* * *}\end{array}$ & $\begin{array}{l}-0.057 \\
(0.996)^{*}\end{array}$ & $\begin{array}{l}-0.223 \\
(0.031)^{* 4}\end{array}$ & $\begin{array}{l}-0.073 \\
(0.000) * * *\end{array}$ & $\begin{array}{l}97.452 \\
(0.000)^{* * *}\end{array}$ & $\begin{array}{l}-1.204 \\
(0.612)\end{array}$ & $\begin{array}{l}-0.911 \\
(0.293)\end{array}$ & $\begin{array}{l}-0.014 \\
(0.022) * *\end{array}$ & $\begin{array}{l}0.386 \\
(0.153)\end{array}$ & 0.236 & 812 \\
\hline \multicolumn{13}{|l|}{ 11. Mature Stage: } \\
\hline Performance & Positive & $\begin{array}{l}4.736 \\
(0.007)^{* 1 *}\end{array}$ & $\begin{array}{l}-0.019 \\
(0.188)\end{array}$ & $\begin{array}{l}-0.091 \\
(0.401)\end{array}$ & $\begin{array}{l}-0.058 \\
(0.0000) * * *\end{array}$ & $\begin{array}{l}96.836 \\
(0.000)^{* * *}\end{array}$ & $\begin{array}{l}-1,085 \\
(0.611)\end{array}$ & $\begin{array}{l}3.562 \\
(0.0002) * * .\end{array}$ & $\begin{array}{l}-0.023 \\
(0.001)^{*=*}\end{array}$ & $\begin{array}{l}0.364 \\
(0.221)\end{array}$ & 0.399 & 632 \\
\hline Discrepancy & Negative & $\begin{array}{l}9.810 \\
(0.000)^{* * 4}\end{array}$ & $\begin{array}{l}-0.108 \\
(0.001)^{4+4}\end{array}$ & $\begin{array}{l}-0.451 \\
(0.000)^{* 4 *}\end{array}$ & $\begin{array}{l}-0.044 \\
(0.000)^{* * 4}\end{array}$ & $\begin{array}{l}77.838 \\
(0.000)^{4 * 4}\end{array}$ & $\begin{array}{l}2.358 \\
(0.210)\end{array}$ & $\begin{array}{l}2.234 \\
(0.054)^{*}\end{array}$ & $\begin{array}{l}-0.026 \\
(0.000)^{* 44}\end{array}$ & $\begin{array}{l}0.539 \\
(0.053)^{*}\end{array}$ & $0.3 \mathrm{II}$ & 724 \\
\hline \multicolumn{13}{|l|}{ III. Stagnant Stagese: } \\
\hline Perfivm & Positive & $\begin{array}{l}5,415 \\
(0.0000)^{* t a t}\end{array}$ & $\begin{array}{l}0.076 \\
(0.099)^{*}\end{array}$ & $\begin{array}{l}-0.245 \\
(0.016)^{* 4}\end{array}$ & $\begin{array}{l}-0.038 \\
(0.000)^{* * t}\end{array}$ & $\begin{array}{l}120.719 \\
(0.0000)^{* * 4}\end{array}$ & $\begin{array}{l}-2.474 \\
(0.083)^{*}\end{array}$ & $\begin{array}{l}2.319 \\
(0.097)^{*}\end{array}$ & $\begin{array}{l}0.003 \\
(0.525)\end{array}$ & $\begin{array}{l}-0.135 \\
(0.599)\end{array}$ & 0.362 & 707 \\
\hline Discrepancy & Negative & $\begin{array}{l}9.954 \\
(0.000)^{* * *}\end{array}$ & $\begin{array}{l}-0.026 \\
(0.578)\end{array}$ & $\begin{array}{l}-0.416 \\
(0.024)^{* t}\end{array}$ & $\begin{array}{l}-0.055 \\
(0.000)^{* * *}\end{array}$ & $\begin{array}{l}147.722 \\
(0.000)^{* * *}\end{array}$ & $\begin{array}{l}-8.765 \\
(0.008)^{* * *}\end{array}$ & $\begin{array}{l}-0.636 \\
(0.856)\end{array}$ & $\begin{array}{l}-0.019 \\
(0.024)^{* *}\end{array}$ & $\begin{array}{l}0.395 \\
(0.343)\end{array}$ & 0.299 & 648 \\
\hline
\end{tabular}

$*, * *$, and $* * *$ represent significance levels of $0.10,0.05$, and 0.01 , respectively. The numbers in the parentheses represent p-value.

Table 11. Regression results using firm age to identify the stages of business life cycle

\begin{tabular}{|c|c|c|c|c|c|c|c|c|c|c|c|c|}
\hline \multicolumn{11}{|c|}{ 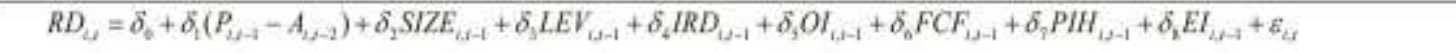 } & \multicolumn{2}{|c|}{ (1) } \\
\hline & Levels & $\delta_{y}$ & $\delta_{1}$ & $\delta_{2}$ & $\delta_{3}$ & $\delta_{4}$ & $\delta_{5}$ & $\delta_{6}$ & $\delta_{7}$ & $\delta_{8}$ & $A d j R^{2}$ & $N$ \\
\hline \multicolumn{13}{|l|}{ L. Growth Stage: } \\
\hline Performance & Positive & $\begin{array}{l}8.405 \\
(0.001)^{*+*}\end{array}$ & $\begin{array}{l}0.040 \\
(0.070)^{*}\end{array}$ & $\begin{array}{l}-0.222 \\
(0.171)\end{array}$ & $\begin{array}{l}-0.079 \\
(0.000)^{*+*}\end{array}$ & $\begin{array}{l}93.876 \\
(0.000)^{*+*}\end{array}$ & $\begin{array}{l}-3.866 \\
(0.026)^{+*}\end{array}$ & $\begin{array}{l}3.370 \\
(0.0000)^{\circ+06}\end{array}$ & $\begin{array}{l}.0 .011 \\
(0.121)\end{array}$ & $\begin{array}{l}0.258 \\
(0.519)\end{array}$ & 0.268 & 594 \\
\hline Discrepancy & Negative & $\begin{array}{l}15.218 \\
(0,0000)^{* 6 *}\end{array}$ & $\begin{array}{l}-0.058 \\
(0.201)\end{array}$ & $\begin{array}{l}-0.647 \\
(0.000)^{40+4}\end{array}$ & $\begin{array}{l}-0.079 \\
(0.000)^{* * *}\end{array}$ & $\begin{array}{l}121.330 \\
(0.000)^{* 0 *}\end{array}$ & $\begin{array}{l}-5,458 \\
(0,061)^{*}\end{array}$ & $\begin{array}{l}0.348 \\
(0.769)\end{array}$ & $\begin{array}{l}0.028 \\
(0.001)^{\infty+20}\end{array}$ & $\begin{array}{l}0.501 \\
(0.305)\end{array}$ & 0.219 & 762 \\
\hline \multicolumn{13}{|l|}{ II. Mature Stage: } \\
\hline Performance & Positive & $\begin{array}{l}4.003 \\
(0.002)^{* * *}\end{array}$ & $\begin{array}{l}0.058 \\
(0.222)\end{array}$ & $\begin{array}{l}0.016 \\
(0.861)\end{array}$ & $\begin{array}{l}-0.070 \\
(0.000)^{* * *}\end{array}$ & $\begin{array}{l}77.182 \\
(0.000)^{* * *}\end{array}$ & $\begin{array}{l}-2.530 \\
(0.056)^{*}\end{array}$ & $\begin{array}{l}-1.264 \\
(0.215)\end{array}$ & $\begin{array}{l}-0.019 \\
(0.001)^{* * * *}\end{array}$ & $\begin{array}{l}0.293 \\
(0.254)\end{array}$ & 0.290 & 619 \\
\hline Discrepancy & Negutive & $\begin{array}{l}7.515 \\
(0.000)^{* * *}\end{array}$ & $\begin{array}{l}-0.034 \\
(0.208)\end{array}$ & $\begin{array}{l}-0.138 \\
(0.104)\end{array}$ & $\begin{array}{l}-0.084 \\
(0.000)^{* * *}\end{array}$ & $\begin{array}{l}85.914 \\
(0.000)^{* * *}\end{array}$ & $\begin{array}{l}-5.787 \\
(0.0012)^{* * *}\end{array}$ & $\begin{array}{l}-40.009 \\
(0.992)\end{array}$ & $\begin{array}{l}0.017 \\
(0.006)^{* * * *}\end{array}$ & $\begin{array}{l}0.235 \\
(0.350)\end{array}$ & 0.273 & 737 \\
\hline \multicolumn{13}{|l|}{ IIL. Stagnant Stage: } \\
\hline Performance & Positive & $\begin{array}{l}3.626 \\
(0.600)^{* 1 *}\end{array}$ & $\begin{array}{l}-0.004 \\
(0.844)\end{array}$ & $\begin{array}{l}-0.213 \\
(0.000)^{* 2 *}\end{array}$ & $\begin{array}{l}0.003 \\
(0.542)\end{array}$ & $\begin{array}{l}88.756 \\
(0.000)^{* \cdots}\end{array}$ & $\begin{array}{l}1.624 \\
(0.134)\end{array}$ & $\begin{array}{l}0.845 \\
(0.242)\end{array}$ & $\begin{array}{l}-0,0077 \\
(0,029)^{* 2}\end{array}$ & $\begin{array}{l}-0.372 \\
(0.095)^{*}\end{array}$ & 0.398 & 670 \\
\hline Discrepancy & Negative & $\begin{array}{l}4.743 \\
(0,000)^{4+6=}\end{array}$ & $\begin{array}{l}-0.088 \\
(0.099)^{2}\end{array}$ & $\begin{array}{l}-0.232 \\
(0,000)^{42 *}\end{array}$ & $\begin{array}{l}-0.011 \\
(0.111)\end{array}$ & $\begin{array}{l}81.990 \\
(0.000)^{2 * 2}\end{array}$ & $\begin{array}{l}-0.478 \\
(0.735)\end{array}$ & $\begin{array}{l}0.585 \\
(0.666)\end{array}$ & $\begin{array}{l}-0.012 \\
(0.015)^{4 *}\end{array}$ & $\begin{array}{l}-0.004 \\
(0.987)\end{array}$ & 0.278 & 685 \\
\hline
\end{tabular}

$*, * *$, and $* * *$ represent significance levels of $0.10,0.05$, and 0.01 , respectively. The numbers in the parentheses represent p-value.

\section{Concluding Remarks}

Companies might miss growth opportunities and lose competitive advantages if their managers fail to make appropriate R\&D decisions in terms of business life cycle. Therefore, it is important for managers to know the effects of business life cycle and performance discrepancies on their R\&D decisions. In this study, we investigate how different stages of business life cycle affect managerial R\&D decisions when firms experience performance discrepancies. The findings indicate that managers of growing firms tend to increase $R \& D$ expenditure when they experience positive performance discrepancy. This implies that growing firms' slack-resource-driven behavior leads to the increase in R\&D expenditure when they experience positive performance discrepancy. There is some evidence that managers of mature firms tend to increase $R \& D$ spending when they experience negative performance discrepancy. The findings also show that managers of mature firms have problem-driven search behavior when they experience negative performance discrepancy. Overall, the findings suggest that managers' slack-resource-driven and problem-driven search behavior may occur under certain circumstances. There is a caveat in this study. Generalization concerns might be raised because the findings are based on Taiwanese firms. Therefore, we encourage future studies to explore the effects of business life cycle and performance discrepancies on managerial $R \& D$ decisions in the global community.

\section{References}

Anthony, J. H., \& Ramesh, K. (1992). Association between Accounting Performance Measures and Stock Prices: A Test of the Life Cycle Hypothesis. Journal of Accounting and Economics, 15(2-3), 203-227. https://doi.org/10.1016/0165-4101(92)90018-W 
Audia, P. G. \& Greve, H. R. (2006). Less Likely to Fail: Low Performance, Firm Size, and Factory Expansion in the Shipbuilding Industry. Management Science, 52(1), 83-94. https://doi.org/10.1287/mnsc.1050.0446

Baum, J. A. C. \& Dahlin, K. B. (2007). Aspiration Performance and Railroads' Patterns of Learning from Train Wrecks and Crashes. Organization Science, 18(3), 368-385. https://doi.org/10.1287/orsc.1060.0239

Black, E. L. (1998). Life-Cycle Impacts on the Incremental Value-Relevance of Earnings and Cash Flow Measure. Journal of Financial Statement Analysis, 4(1), 40-56.

Bolton, M. K. (1993). Organizational Innovation and Substandard Performance: When Is Necessity the Mother of Innovation? Organization Science, 4(1), 57-75. https://doi.org/10.1287/orsc.4.1.57

Bos, J. W. B., Economidou, C., \& Sanders, M. W. J. L. (2013). Innovation over the Industry Life-Cycle: Evidence from EU Manufacturing. Journal of Economic Behavior \& Organization, 86, 78-91. https://doi.org/10.1016/j.jebo.2012.12.025

Bromiley, P. (1991). Testing a Causal Model of Corporate Risk Taking and Performance. Academy of Management Journal, 34(1), 37-59. https://doi.org/10.2307/256301

Bushee, B. J. (1998). The Influence of Institutional Investors on Myopic R\&D Investment Behavior. Accounting Review, 73(3), 305-333.

Chen, W. D. \& Miller, K. D. (2007). Situational and Institutional Determinants of Firms' R\&D Search Intensity. Strategic Management Journal, 28(4), 369-381. https://doi.org/10.1002/smj.594

Chiang, S., Lee, P., \& Anandarajan. A. (2012). The Effect of R\&D Tax Credit on Innovation: A Life Cycle Analysis. Innovation: Management, Policy \& Practice, 14(4), 510-523. https://doi.org/10.5172/impp.2012.14.4.510

Comin, D., \& Mulani, S. (2009). A Theory of Growth and Volatility at the Aggregate and Firm Level. Journal of Monetary Economics, 56(8), 1023-1042. https://doi.org/10.1016/j.jmoneco.2009.10.004

Cyert, R. M. \& March, J. G. (1963). A Behavioral Theory of the Firm, 2nd ed., New Jersey: Prentice-Hall, Englewood Cliffs, NJ.

D'Aveni R. A. (1989). The Aftermath of Organizational Decline: A Longitudinal-Study of the Strategic and Managerial Characteristics of Declining Firms. Academy of Management Journal, 32(3), 577-605. https://doi.org/10.2307/256435

Dodge, R. H. \& Robbins, J. E. (1992). An Empirical Investigation of the Organizational Life Cycle Model for Small Business Development and Survival. Journal of Small Business Management, 1, 27-37.

Dutta, S., Narasimhan, O., \& Rajiv, S. (1999). Success in High-Technology Market: Is Marketing Capability Critical? Marketing Science, 18(4), 547-568. https://doi.org/10.1287/mksc.18.4.547

Greve, H. R. (1998). Performance, Aspirations, and Risky Organizational Change. Administrative Science Quarterly, 44(1), 58-86. https://doi.org/10.2307/2393591

(2003a). Organizational Learning from Performance Feedback: A Behavioral Perspective on Innovation and Change, Cambridge: Cambridge University Press.

(2003b). A Behavioral Theory of R\&D Expenditures and Innovations: Evidence from Shipbuilding. Academy of Management Journal, 46(6), 685-702 . https://doi.org/10.2307/30040661

(2008). A Behavioral Theory of Firm Growth: Sequential Attention to Size and Performance Goals. Academy of Management Journal, 51(3), 476-494. https://doi.org/10.5465/AMJ.2008.32625975

, \& Taylor, A. (2000). Innovations as Catalysts for Organizational Change: Shifts in Organizational Cognition and Search. Administrative Science Quarterly, 45(1), 54-80. https://doi.org/10.2307/2666979

Helfat, C. E. \& Peteraf, M. A. (2003). The Dynamic Resource-based View: Capability Lifecycles. Strategic Management Journal, 24(10), 997-1010. https://doi.org/10.1002/smj.332

Hill, C. W. L. (2010). Strategic Management Theory: An Integrated Approach, 9th ed., Mason: South-Western/Cengage Learning.

Iyer, D. N. \& Miller, K. D. (2008). Performance, Feedback, Slack, and the Timing of Acquisition. Academy of Management Journal, 51(4), 808-822. https://doi.org/10.5465/AMR.2008.33666024

Kahneman, D. \& Tversky, A. (1979). Prospect Theory: An Analysis of Decision under Risk. Econometrica, 47(2), 263-291. https://DOI.org/10.2307/1914185 
Ketchen, D. J. \& Palmer, T. B. (1999). Strategic Responses to Poor Organizational Performance: A Test of $\begin{array}{llll}\text { Competing Perspectives. Journal of } & \text { Management, }\end{array}$ https://doi.org/10.1016/S0149-2063(99)00021-5

Kobelsky, K. W., Richardson, V. J., Smith, R. E., \& Zmud, R. W. (2008). Determinants and Consequences of Firm Information Technology Budgets. Accounting Review, 83(4), 957-995. https://doi.org/10.2308/accr.2008.83.4.957

Lant, T. K. (1992). Aspiration Level Adaptation: An Empirical Exploration. Management Science, 38(5), 623-644. https://doi.org/10.1287/mnsc.38.5.623

Latham, S. F., \& Braun, M. (2009). Managerial Risk, Innovation, and Organizational Decline. Journal of Management, 35(2), 258-281. https://doi.org/10.1177/0149206308321549

Leonard-Barton, D. A. (1992). Core Capabilities and Core Rigidities: A Paradox in Managing New Product Development. Strategic Management Journal, 13(1), 111-126. https://doi.org/10.1002/smj.4250131009

Lev, B. \& Sougiannis, T. (1996). The Capitalization, Amortization, and Value-Relevance of R\&D. Journal of Accounting and Economics, 21(1), 107-138. https://doi.org/10.1016/0165-4101(95)00410-6

Levinthal, D. A. \& March, J. G. (1993). The Myopia of Learning. Strategic Management Journal, 14(8), 95-112. https://doi.org/10.1002/smj.4250141009

Lin, S. H., Chen, Y. J., Wang, T. L., \& Liu, Y. C. A. (2012). FDIs in Life Cycle Stages: Firm-Level Evidence from Taiwan. Applied Economics Letters, 19, 393-397. https://doi.org/10.1080/13504851.2011.581197

McAdam, R., \& Mitchell, N. (2010). The Influence of Critical Incidents and Life Cycle Dynamics on Innovation Implementation Constructs in SMEs: A Longitudinal Study. International Journal of Technology Management, 52(1/2), 189-212. https://doi.org/10.1504/IJTM.2010.035862

March, J. G. \& Shapira, Z. (1992). Variable Risk Preferences and the Focus of Attention. Psychological Review, 99(1), 172-183. https://doi.org/10.1037/0033-295X.99.1.172

Miller, K. D. \& Chen, W. R. (2004). Variable Organizational Risk Preferences: Tests of the March-Shapira Model. Academy of Management Journal, 47(1), 105-116. https://doi.org/10.2307/20159563

\& Friesen, P. H. (1984). A Longitudinal Study of the Corporate Life Cycle. Management Science, 30(10), 1161-1183. https://doi.org/10.1287/mnsc.30.10.1161

Porter, M. E. (1998). Competitive Strategy: Techniques for Analyzing Industries and Competitors: With a New Introduction, 1st ed., New York: Free Press.

Quinn, R. E. \& Cameron, K. S. (1983). Organizational Life Cycles and Shifting Criteria of Effectiveness: Some Preliminary Evidence. Management Science, 29(1), 33-51. https://doi.org/10.1287/mnsc.29.1.33

Schneider, S. L. (1992). Framing and Conflict: Aspiration level Contingency, the Status Quo, and Current Theories of Risky Choice. Journal of Experimental Psychology: Learning, Memory, and Cognition, 18(5), 1040-1057. https://doi.org/10.1037//0278-7393.18.5.1040

Shimizu, K. \& Hitt, M. A. (2005). What Constraints or Facilitates Divestitures of Formerly Acquired Firms? The Effects of Organizational Inertia. Journal of Management, 31(1), 50-72. https://doi.org/10.1177/0149206304271381

Staw, B. M., Sandelands, L.E., \& Dutton, J. E. (1981). Threat-Rigidity Effects in Organizational Behavior: A Multilevel Analysis. Administrative Science Quarterly, 26(4), 501-524. https://doi.org/10.2307/2392337

Tushman, M. \& Nadler, D. (1986). Organizing for Innovation. California Management Review, 28(3), 74-92. https://doi.org/10.2307/41165203

White, H. (1980). A Heteroskedasticity-Consistent Covariance Matrix Estimator and a Direct Test for Heteroskedasticity. Econometrica, 48(4), 817-838. https://doi.org/10.2307/1912934

Wiseman, R. M. \& Bromiley, P. (1996). Toward a Model of Risk in Declining Organizations: An Empirical Examination of Risk, Performance and Decline. Organization Science, 7(4), 524-543. https://doi.org/10.1287/orsc.7.5.524

Wöhrl, R., Hüsig, S., Dowling, M. (2009). The Interaction of R\&D Intensity and Firm Age: Empirical Evidence from Technology-Based Growth Companies in the German "Neuer Markt". Journal of High Technology Management Research, 20, 19-30. https://doi.org/10.1016/j.hitech.2009.02.006 